\title{
Governance and Development: Changing EU Policies ${ }^{1}$
}

\author{
Wil Hout \\ International Institute of Social Studies, Erasmus University, PO Box 29776, 2502 LT \\ The Hague, The Netherlands.Email: hout@iss.nl.
}

\begin{abstract}
This introductory article to the special issue on European Union, development policies and governance discusses how notions of ('good') governance came to dominate development discourses and policies since the mid-1990s. The article argues that governance was part of the socalled Post-Washington Consensus, which understands governance reform as part of the creation of market societies. Despite the fact that academics have commonly emphasised that governance concerns the rules that regulate the public sphere, the dominant understanding of (good) governance in policy circles revolves around technical and managerial connotations. The second part of the article introduces some important features of EU development policy, and argues that this is essentially neo-liberal in nature and that it favours a technocratic approach to governance reform. The EU's main instrument in relations with developing countries is the Country Strategy Paper, which includes a set of governance indicators for the assessment of the political situation in partner countries. In addition, the European Union has developed a 'governance profile', which consists of nine components.
\end{abstract}

\section{The Rise of Governance}

Since the mid-1990s, conceptions of governance have occupied a central place in development discourses and policies. Academically, the rise of the governance concept can be attributed, to an important extent, to the institutionalist wave that has swept across the social sciences. ${ }^{2}$ For the policy world, the emphasis of institutions and governance in the so-called new institutional economics, and the embrace of the latter by the World Bank, was highly relevant. Governance came to the rescue of neoliberal approaches to development, which were experiencing a crisis as a result of the failure of 'marketfundamentalist' structural adjustment policies. ${ }^{3}$

The adoption of governance into the vocabulary of development has, in the words of some observers, been interpreted as a change from the market-based 'Washington 
Consensus' to an institution-oriented 'Post-Washington Consensus'. As famously argued by former World Bank chief economist Joseph Stiglitz,

the policies advanced by the Washington Consensus are not complete, and they are sometimes misguided. Making markets work requires more than just low inflation; it requires sound financial regulation, competition policy, and policies to facilitate the transfer of technology and to encourage transparency, to cite some fundamental issues neglected by the Washington Consensus. ${ }^{4}$

The argument adopted by Stiglitz and others was that attention for governance and institutions had proven to be a necessary complement to the building or deepening of markets. Thus, it was argued, specific institutional frameworks are necessary counterweights to 'market failure'.

The reasoning that the focus on governance represented a change away from market fundamentalism has been challenged by various scholars, ${ }^{5}$ who argue that the PostWashington Consensus is essentially neoliberal in character, as it continues to see the market as the preeminent, fundamentally benign force of development, and the state as being subject to the interest of rent-seeking actors.

One of the main implications of the adoption of the governance concept into the neoliberal development framework, which perceived governance in function of the building of markets, is that it came to be understood in predominantly technocratic terms. As the World Bank has stated it, "[t]he ability of the state to provide institutions that make markets more efficient is sometimes referred to as good governance'. ${ }^{6}$ Thus, 'good governance' seeks to ensure efficiency in public administration and public finance management, rule of law, decentralisation and regulation of corporate life, including competition laws and anti-corruption watchdogs, arms-length procurement processes and the outsourcing of public services and supply. Conceived as a form of authority outside politics and the traditional realm of administration, it is a means to claim autonomy for technocratic authority from what are seen as distributional coalitions.

'Good governance' approaches of development agencies tend to take one of two forms. The first of these approaches has been taken by those agencies that interpret governance quality as a prerequisite for the effectiveness of development and associated aid instruments. This use of governance has its origins in the analyses of Burnside and 
Dollar on aid effectiveness. According to these two World Bank analysts, development assistance would be effective only in countries that have adopted good governance and good policies. ${ }^{7}$ Various development agencies applied this logic since the late 1990s with the adoption of selectivity principles in aid allocation. For example, the World Bank implemented performance-based allocation to loans and grants given by its International Development Agency (IDA), while the United States adopted the Millennium Challenge Account. ${ }^{8}$ The European Union has moved in this direction to a certain extent with the adoption into the ACP framework of a 'governance incentive tranche', which should lead to allocations of aid funds on the basis of the governance situation and reform commitments in recipient countries. ${ }^{9}$

The second approach to 'good governance' has been applied by agencies that take the improvement of governance and the strengthening of institutions as the prime target of assistance policies. This position is located more squarely within dominant development policies, which see the building of (state) institutions as a major objective of foreign aid. As was the case with the first approach to governance highlighted above, these policies find support in the strategy advocated by the World Bank, that '[e]ffective aid supports institutional development and policy reforms that are at the heart of successful development'. ${ }^{10}$ The EU's orientation to this approach can be found, among others, in the recent identification of issue areas where European Community aid was felt to have clear value added, and which mentioned 'institutional capacity building' as the sixth target. ${ }^{11}$

The dominant understanding of (good) governance in policy circles fails to recognise the essentially political character of governance issues, which relate to existing power relations in society and concern 'the formation and stewardship of the formal and informal rules that regulate the public realm, the arena in which state as well as economic and societal actors interact to make decisions'. ${ }^{12}$ Problems such as the access of marginalised groups to political decision-making or the attempts of powerful groups to manipulate governance reform to their advantage have generally received much less attention from the development agencies than public sector reform, public finance management and decentralisation, to mention but three popular issues. ${ }^{13}$

\section{Europe as a Development Actor}


This special issue of the Third World Quarterly takes stock of the ways in which one of today's most important development actors, the European Union, ${ }^{14}$ has implemented policies related to governance in its external development relations. The thrust of the argument presented in the following contributions is that EU development policies are essentially neo-liberal in character and that their governance-related strategies in effect display a technocratic orientation and are instrumental to deepening market-based reform in aid-receiving countries.

\subsection{EU Development Assistance}

In recent years, the European Union has become one of the major multilateral agencies in the field of development assistance. Not counting the aid flows originating from the EU member states, European development assistance increased to $\$ 11.6$ billion in 2007, which amounted to over one-and-a-half times the aid provided by the World Bank through its IDA window in the same year. ${ }^{15}$ The three main objectives of EU development assistance, according to article 177 of the Treaty Establishing the European Community, are:

- the sustainable economic and social development of the developing countries;

- the smooth and gradual integration of these countries into the world economy; and - the campaign against poverty.

EU development assistance policies are seen as 'complementary' to those of the member states.

The main target of EU development policies has traditionally been the group of member states' former colonies in Africa, the Caribbean and the Pacific (commonly referred to as ACP countries). After an initial period in which contacts with the former African colonies were regulated by the 'Regime of Association' (1957) and two Yaoundé Conventions (1963-1975), European relations with the ACP have been governed by four Lomé Conventions (1976-2000) and the Cotonou Agreement (since 2000), which included aid and trade instruments. Institutionally, support for the ACP countries has 
been financed through the European Development Fund, which is replenished periodically by the EU member states.

Aid to the ACP countries has continued to account for a sizeable proportion of total EU development assistance. Since the coming into force of the Cotonou Agreement, aid to the ACP has increased from slightly under $€ 2$ billion in 2001 to $€ 4.8$ billion in 2008 . ACP's relative share in EU external assistance has remained more or less stable, at 35.4 per cent in 2001 and 37.8 per cent in 2008. In 2005, member states pledged $€ 22.7$ billion to the European Development Fund, to be allocated to the ACP countries between 2007 and $2013 .^{16}$

Table 1: Regional Distribution of Aid Commitments to Developing Countries (ODA), 2004 and 2008

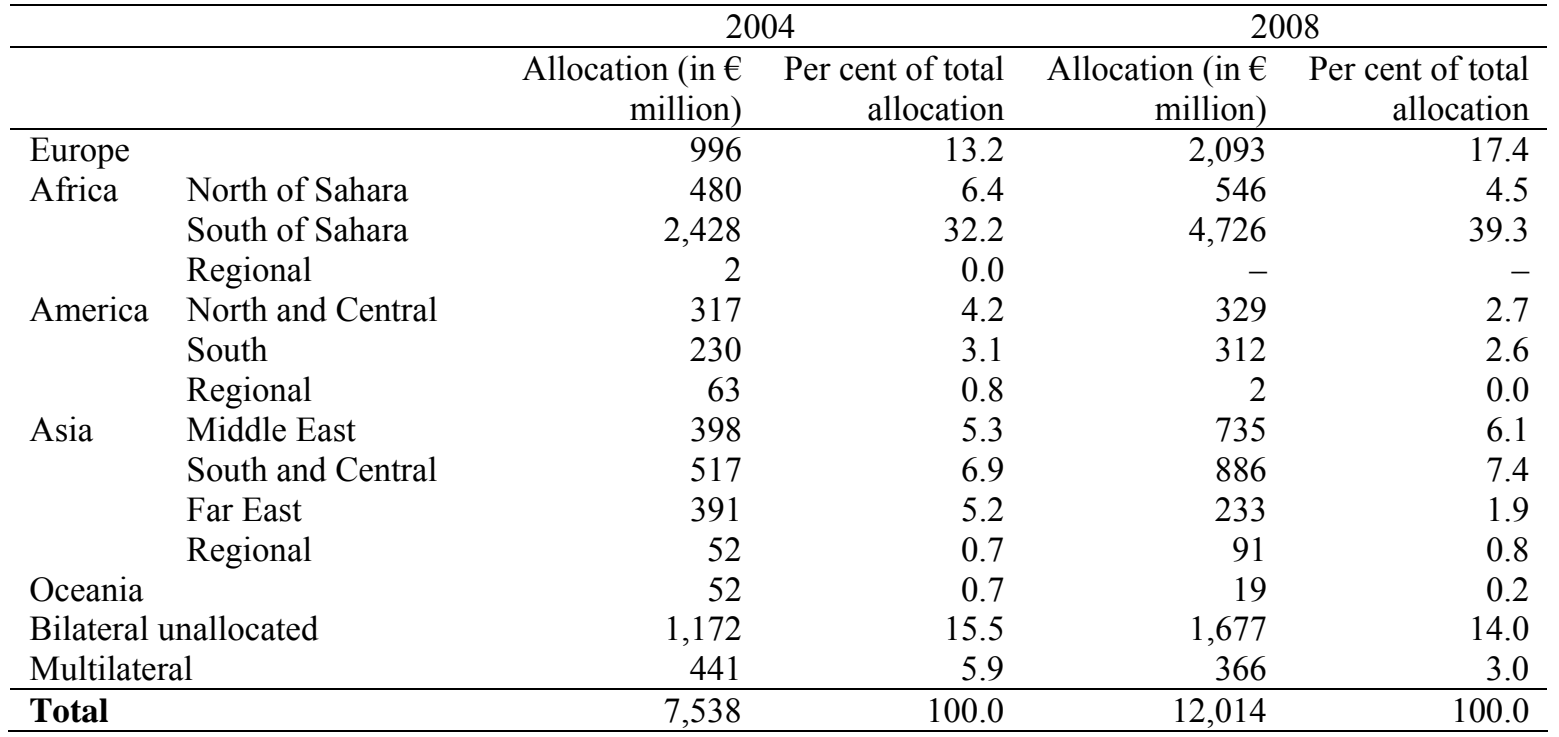

Source: European Commission, Annual Report 2009 on the European Community's Development and External Assistance Policies and their Implementation in 2008, SEC(2009)831 final, 30 June 2009, p 200.

Apart from its agreements with the ACP, the European Union has maintained relations with most other regions in the developing world. Assistance to non-ACP countries is not financed out of the EDF, but is included in the regular EU budget for development aid, usually referred to as the Development Cooperation Instrument (DCI). Particularly important is the EU's European Neighbourhood Policy, which covers such diverse regions as the Middle East, North Africa and six former Soviet republics in Eastern Europe and the Caucasus. Table 1 shows that the EU's external assistance has retained its 
focus on these countries: aid to countries in the Middle East increased from 5.3 to 6.1 per cent between 2004 and 2008, while Eastern European countries saw their share grow from 13.2 to 17.4 per cent. The share of North African countries decreased in relative terms (from 6.4 in 2004 to 4.5 per cent in 2008), although the absolute amount of aid to this region grew by approximately 14 per cent. Aid to Asian countries (excluding the Middle East) fell in relative terms from 12.8 per cent of total European aid in 2004 to 10.1 per cent in 2008. Although the EU has developed ideas on a partnership with Latin America, the share of EU aid flowing to countries in this part of the world has dropped from 8.1 per cent in 2004 to 5.3 per cent in 2008.

In terms of policy formulation, the European Council and European Commission have exhibited much activity in the area of development cooperation since the turn of the century, as evidenced by a joint statement on development policy issues in November 2000. This declaration focused on poverty reduction as the 'principal aim' of the EU's development policy and highlighted the need to 'refocus' its activities to a limited number of sectoral priorities in order to enhance impact. EU development assistance was argued to provide value added in the following six issue areas:

- the link between trade and development;

- regional integration and cooperation;

- support for macro-economic policies and the promotion of equitable access to social services;

- transport;

- food security and sustainable rural development; and

- institutional capacity building. ${ }^{17}$

Several years later, in December 2005, the European Council, Commission and Parliament agreed on another joint statement, labelled the 'European Consensus on Development' in a clear attempt to juxtapose it to the Washington Consensus dominated by the World Bank and the US government. The European Consensus was an attempt to formulate "for the first time, a common vision that guides the action of the EU, both at its Member States and Community levels, in development co-operation' ${ }^{18}$ According to the 
Consensus, '[t]he primary and overarching objective of EU development cooperation is the eradication of poverty in the context of sustainable development, including pursuit of the Millennium Development Goals (MDGs) ${ }^{,}{ }^{19}$ Several 'common principles' of European development cooperation were laid down; most notably, these were: ownership and partnership; the need for engaging in political dialogue with developing countries; the participation of civil society, including economic and social partners; the promotion of gender equality and women's rights; and the attention for state fragility. ${ }^{20}$ Aid effectiveness would be enhanced, according to Council, Commission and Parliament, by concentrating development assistance on a limited number of activities where the EU would possess a 'comparative advantage'. The activities that were singled out, were the following:

- trade and regional integration;

- the environment and the sustainable management of natural resources;

- infrastructure, communications and transport;

- water and energy;

- rural development, territorial planning, agriculture and food security;

- governance, democracy, human rights and support for economic and institutional reforms;

- conflict prevention and fragile states;

- human development; and

- social cohesion and employment. ${ }^{21}$

\subsection{EU Development Assistance and Governance}

The main tool in the relationship between the European Community and partner developing countries is the Country Strategy Paper. In line with the practice of many international development agencies, the European Community formulates a medium-term strategy for the provision of development assistance on the basis of a country's official national policy priorities. Developing countries have usually laid down their priorities in Poverty Reduction Strategy Papers (PRSPs), which are required for getting support from the World Bank and IMF. According to the European Commission, the establishment of a 
common framework for the formulation of CSPs makes 'a significant contribution to achieving the goal of multiannual programming and to increasing the effectiveness and quality of the EU's external aid'. ${ }^{22}$

As part of the 'country diagnosis', a Country Strategy Paper is required to contain an analysis of the political - along with the economic, social and environmental - situation in the partner country. An important set of governance indicators is included among the assessment of the political situation, such as:

- the main obstacles at the national level for the protection of and respect for human rights;

- the observance of democratic principles, as related to elections and change of government;

- the organisation of the government and decision-making procedures, including the division of power over different levels of government, transparency and accountability of key political institutions, measures countering corruption and other forms of economic criminality, and the rule of law and the independence of the judiciary; and

- evidence pointing at state fragility, such as the incapacity to perform basic government functions (security, social services and human rights). ${ }^{23}$

In addition to applying these indicators, the European Commission has argued that in fragile states, post-conflict countries and specific cases of countries that have yet to achieve 'structural stability' or are showing signs of increasing instability, greater attention should be given to analysing measures taken to ensure security and stability, including conflict prevention and management, post-conflict intervention strategies (demobilisation, disarmament, re-integration (in particular of women and child soldiers), rebuilding, humanitarian mine clearance, support for action against illegal arms trafficking and dissemination of small arms and light weapons, etc.), and the introduction of the rule of law and democracy (including broader participation of civil society and a more equitable distribution of power) ${ }^{24}$

Accompanying the Communication on 'Governance in the European Consensus', the European Commission published a methodology for assessing developing countries' governance quality. In the first instance the so-called 'governance profile' was developed for ACP countries, but later releases of the profile have dropped the reference to only the 
ACP group. The profile was set up as a 'programming tool', the main objectives of which are 'to help identifying specific areas of cooperation (weaknesses) and agreeing on benchmarks and targets for reform (Government commitments), or on sectoral performance indicators, if governance is a focal area ${ }^{25}$. The governance profile was meant for application by the European Commission, and would not necessarily reflect a common understanding of governance quality in the recipient country: 'The governance profile is not meant to be done necessarily jointly with the partner country but its content should be shared (but not negotiated and agreed) with partner country during the programming dialogue'. ${ }^{26}$

The governance profile developed by the European Commission consists of nine components, which are subdivided into a variety of specific issues. The profile is summarised in table 2. The governance profile as used by the European Commission draws heavily on the work done by staff at the World Bank Institute, resulting in the Worldwide Governance Indicators dataset. ${ }^{27}$ The first six components are based on the six elements of the Worldwide Governance Indicators. The final three indicators (on social governance, international and regional context, and quality of partnership) have been developed by staff at the Commission. Of the nine components, two (political/democratic governance and internal and external security) seem to address political issues of governance most directly, while two (internal and external security, and international and regional context) appear to be most directly related to the problems faced by fragile states. Two components (political governance/rule of law and control of corruption) primarily assess the presence of legal instruments, while two (government effectiveness and economic governance) are essentially meant to scrutinise the management of economic policies and policy-making. The component on social governance relates to the implementation of a variety of social policies. The final component is geared to assessing the implementation of EU development projects and programmes. Also, the inclusion of an item on migration in the eighth component appears to be informed mainly by concerns in the European Union about possible immigration. ${ }^{28}$

Table 2: The European Commission's Governance Profile

\begin{tabular}{|l|l|}
\hline \hline Components & Items \\
\hline 1. Political/democratic governance & a. Human rights \\
\hline
\end{tabular}




\begin{tabular}{|l|l|}
\hline \multicolumn{1}{|c|}{ (WBI's Voice and accountability) } & b. Fundamental freedoms \\
\hline & c. Electoral process \\
\hline $\begin{array}{l}\text { 2. Political governance/rule of law: } \\
\text { Judicial and law enforcement system }\end{array}$ & d. Principles of constitutional democracy \\
\hline 3. Control of corruption & \\
\hline 4. Government effectiveness & a. Institutional capacity \\
\hline & b. Public finance management \\
\hline 5. Economic governance (WBI's & a. Private sector/market-friendly policies \\
\hline Regulatory quality) & b. Management of natural resources \\
\hline 6. Internal and external security (WBI's & a. Internal stability/conflict \\
\hline \multicolumn{1}{|c|}{ Political stability and absence of violence) } & b. External threats and global security \\
\hline 7. Social governance & a. Regional integration \\
\hline 8. International and regional context & b. Involvement in regional initiatives on governance \\
& and peer-review mechanisms (such as APRM) \\
\hline & c. Migration \\
\hline 9. Quality of partnership & a. Political dialogue \\
\hline & b. Programming dialogue \\
\hline & c. Non-state actors \\
\hline \hline
\end{tabular}

Source: European Commission, Staff Working Document Accompanying the Communication 'Governance in the European Consensus on Development: Towards a Harmonized Approach within the European Union', SEC(2006)1020, 30 August 2006, pp. 13-29.

Note: WBI refers to the World Bank Institute's Governance Matters indicators.

\section{Outline of this Special Issue}

The contributions to this special issue contest recent EU approaches to governance and development. As highlighted above, the articles are informed by the general understanding that the EU's approach to development and governance is essentially neoliberal in character and reflects a technocratic, instrumental orientation premised on the need to deepen market-based reforms in the countries of the south.

The first article, by Maurizio Carbone, discusses the EU's take on governance in the context of the development policies that have been implemented since the turn of the century. In particular, Carbone focuses on the attempt of the European Commission to harmonise the approach to governance, revolving around the idea of 'democratic governance'. The article argues that the EU's initiative seems to have been in line with the principles of aid effectiveness stemming from the Paris Declaration, but that implementation of the policy is lacking. Such 'policy evaporation' seems to be caused, to a significant extent, by the difficulty to achieve intra-EU coordination. A direct consequence of this appears to be a decrease of the leverage of developing countries in relation to the European Union. 
Nikki Slocum-Bradley and Andrew Bradley, in their article, focus on the relationship with countries in Africa, the Caribbean and Latin America (ACP) since the adoption of the Cotonou Agreement in 2000. Discussing various instruments that have been applied in EU-ACP relations, the authors assess to what extent these relations conform to the EUendorsed principles of 'good governance', and whether they seem to contribute to sustainable development and poverty reduction in the ACP countries. Slocum-Bradley and Bradley conclude that the governance rhetoric adopted by the European Union is contradicted, in a good number of cases, by the implementation of policies, and that EU instruments are not necessarily conducive to the development of ACP partners.

In the third article, Ian Taylor discusses the relations between the European Union and Africa, more in particular the EU position on NEPAD and its governance aspirations. According to Taylor, Western support of NEPAD's neo-liberal, technocratic agenda took insufficient account of the nature of the regimes in Africa and, more importantly, the political economy of rule in many countries of the continent. Thus, Western countries ended up supporting the personalised power structures of rulers who showed little or no commitment to the principles of good governance preached by the donors. Finally, the increased importance of China as a partner of African governments may make the EU's emphasis of governance largely irrelevant, although Taylor points out that, in the longer run, China may be motivated by similar concerns about the governance of African countries as the European Union.

David Chandler, in his article on the EU and Southeastern Europe, focuses on the impact that EU is having on the candidate member states in the region. According to Chandler, the EU is exercising considerable regulatory power over the countries of Southeastern Europe, based on essentially depoliticised and technocratic conceptions of management. The EU's approach to the region, Chandler argues, is based on a 'postliberal' discourse of governance, which focuses on technical and administrative capacity rather than legitimacy. The EU, while couching its methods of rule in terms of partnership and ownership, is dominating the region by, among others, Europeanising the candidate states' governance institutions and attempting to create a policy-advocating civil society. The state institutions in the regions have consequently been bereft of their possibilities to engage with and represent social interests. 
In her article on EU relations with the former Soviet republics of Central Asia, Katharina Hoffmann focuses on the claim that the recent EU partnership strategy for the region is aimed at the promotion of good governance. Building on the literature on external democracy promotion, in particular, in relation to post-communist countries, Hoffmann argues that the regimes of the Central Asian countries have essentially remained authoritarian after the disappearance of the Soviet Union. She indicates that the regimes invariably have retained neopatrimonial features, such as personalised power and the monopolisation of resources by the regime. In such an environment, the promotion of good governance is not likely to be successful. Hoffmann explains the continued engagement of the European Union, despite the absence of progress in the area of governance and democratisation, with reference to the EU's security and economic interests that revolve around the access to sources of energy (in particular, natural gas) and the concern about terrorism, drug trafficking and organised crime.

In the next article, Karim Knio discusses the EU's strategy for the Mediterranean, and focuses on the discussion surrounding the creation of a Euro-Mediterranean Development Bank (EMDB) for the countries in the region. The article revolves around the polarity in the literature on governance and institutions. According to Knio, there is a stark contrast between the 'techno-managerial' position in the institutionalist literature, which can be considered to be 'power insular', and certain 'power sensitive' approaches, which focus on interests and power dynamics underlying certain governance arrangements. The two 'faces' of governance are represented, Knio argues, in the debate about the EuroMediterranean Development Bank. The first approach to the Bank emphasises the limited mandate and subordinate role of the EMDB to its parent institution, the European Investment Bank, allowing little influence by the Mediterranean countries. The second approach stresses the independence of the EMDB, and grants the countries of the region a say in its governance structure. Knio concludes that the technocratic approach of the European Union prevailed, thus leading to the maintenance of an institution that would primarily assist small- and medium-sized enterprises in the region.

Rosalba Icaza's article addresses the neo-liberal nature of the European Union's approach to Latin America and the Caribbean, as well as the resistance to the regional project within the region's civil society. Icaza argues that the strategic partnership for the 
region on the side of the EU was driven primarily by the desire to liberalise trade and investment. In her view, market actors, most notably multinational companies, are seen as the key drivers of regionalism and development. This approach to regionalism is contrasted with approaches that emphasise resistance to neo-liberal regionalism and claims for 'cognitive justice'. The latter approaches question the claims made for neoliberal modes of governance and aim at increasing the political visibility of forms of knowledge that would normally be ignored. Icaza's article analyses the activities of the so-called Permanent People's Tribunals against European Multinationals and Neoliberalism as attempts at questioning the violations of rights of Latin American people by European MNCs or their local subsidiaries.

The last research article of this special issue, by Wil Hout, focuses on the European Union's approach to governance in failed states. Arguing that the EU's fragile state agenda was spurred, in the first place, by the desire to address security issues in developing countries, the article emphasises that the EU, as most Western development agencies, has approached state fragility primarily in terms of a governance deficit. Hout analyses the governance-oriented measures that were adopted in the Country Strategy Papers (CSPs) that the European Commission has formulated in consultation with the governments of five so-called fragile states. He concludes that there is a substantial difference between the political analyses made in the CSPs and the policies adopted by the EU for reconstructing governance in fragile states, which consist mainly of technocratic measures. Issues of state capture, human rights and inequalities are generally left unaddressed in the EU' approach.

Stephen Hurt's review article discusses five recent books on EU development policy. Hurt focuses on four main themes in the books under review: the historical legacies, the global context, the increasing uniformity of the EU's approach to different parts of the developing world, and the role of self-interest. Hurt emphasises the EU's strategy of attempting to lock-in liberal capitalism to regional projects across the developing world. He also argues that, apart from ideological motives related to the emphasis of the Millennium Development Goals, self-interest has started to occupy a more important role in EU development policies in recent times. The difficulty in reconciling principles of 
policy coherence with the EU's approach to development and external relations, according to Hurt, is witness to this tension.

\section{Notes}

${ }^{1}$ The articles in this special issue have greatly benefited from the support received from the working group on North-South Development Issues that was part of the EU-supported Network of Excellence on Global Governance, Regionalisation and Regulation (GARNET). The articles were discussed at two workshops held at the International Institute of Social Studies (ISS) in July and November 2008, as well as at the 4th GARNET Annual Conference in Madrid in November 2009.

${ }^{2}$ For instance, see S N Sangmpam, 'Politics Rules: The False Primacy of Institutions in Developing Countries', Political Studies, 55(1), 2007, pp 201-224.

${ }^{3}$ Among others, see D Craig and D Porter, Development Beyond Neoliberalism? Governance, Poverty Reduction and Political Economy, London: Routledge, 2006.

${ }^{4} \mathrm{~J}$ E Stiglitz, More Instruments and Broader Goals: Moving toward the Post-Washington Consensus, WIDER Annual Lectures 2, Helsinki: UNU World Institute for Development Economics Research, 1989, p 1.

${ }^{5}$ For instance, Craig and Porter, Development Beyond Neoliberalism?, p 93, and Z Öniş and F Şenses, 'Rethinking the Emerging Post-Washington Consensus', Development and Change, 36(2), 2005, p 285. ${ }^{6}$ World Bank, Building Institutions for Markets: World Development Report 2002, New York: Oxford University Press, 2002, p 99.

${ }^{7}$ C Burnside and D Dollar, Aid, Policies and Growth, World Bank Policy Research Working Paper 1777, Washington, D.C.: World Bank, 1997 and C Burnside and D Dollar, Aid, Policies, and Growth: Revisiting the Evidence, World Bank Policy Research Working Paper 3251, Washington, D.C.: World Bank, 2004. ${ }^{8}$ See, e.g., W Hout, The Politics of Aid Selectivity: Good Governance Criteria in U.S., World Bank and Dutch Foreign Assistance, London: Routledge, 2007.

${ }^{9}$ European Commission, Governance in the European Consensus on Development: Towards a Harmonised Approach within the European Union, Communication from the Commission to the Council, the European Parliament, the European Economic and Social Committee and the Committee of the Regions, COM(2006)421 final, 30 August 2006, p 12.

${ }^{10}$ World Bank, Assessing Aid: What Works, What Doesn't and Why, New York: Oxford University Press, 1998, p ix.

${ }^{11}$ European Community, Development Policy of the European Community - Statement by the Council and the Commission, 2000, pp 3-6, at http://ec.europa.eu/development/icenter/repository/council20001110_en.pdf, accessed 28 August 2009.

${ }^{12} \mathrm{G}$ Hyden, J Court and K Mease, Making Sense of Governance: Empirical Evidence from 16 Developing Countries, Boulder: Lynne Rienner, 2004, p 16.

${ }^{13}$ Cf. R Robison, 'Strange Bedfellows: Political Alliances in the Making of Neo-liberal Governance', in Governance and the Depoliticisation of Development, W Hout and R Robison (eds), London: Routledge, 2009, pp 17-20.

${ }^{14}$ In this issue, the term 'European Union development policies' will refer to the policies implemented at the level of the Union. Formally speaking, on the basis of the Treaty of Maastricht of 1992, development policy is part of the first 'pillar' of the European Union. This pillar is also referred to as the European Community, and is regulated by articles $177-181$ of the Treaty Establishing the European Community. The common development policies of the EU are implemented by the European Commission. In case analyses refer to the assistance policies of the member states in addition to Community policies, this will be mentioned explicitly.

${ }^{15}$ Organisation for Economic Co-operation and Development, OECD.Stats, Table 2A: ODA

Disbursements, at http://stats.oecd.org/Index.aspx?DatasetCode=TABLE2A, accessed 28 August 2009. 
${ }^{16}$ European Commission, Highlights - Annual Report 2006 on the European Community's Development Policy and the Implementation of External Assistance in 2005, Luxembourg: Office for Official Publications of the European Communities, 2006, p 12; Annual Report 2006 on the European Community's Development Policy and the Implementation of External Assistance in 2005, Luxembourg: Office for Official Publications of the European Communities, 2006, p 9; Annual Report 2009 on the European Community's Development and External Assistance Policies and their Implementation in 2008, SEC(2009)831 final, 30 June 2009, p 196.

${ }^{17}$ European Community, Development Policy of the European Community, pp 3-6.

${ }^{18}$ European Union, 'The European Consensus on Development', Joint Statement by the Council and the Representatives of the Governments of the Member States Meeting within the Council, the European Parliament and the Commission, Official Journal of the European Union, 24 February 2006, C46/01, pp 119.

${ }^{19}$ Ibid, pp 2.

${ }^{20}$ Ibid, pp 3-5.

${ }^{21}$ Ibid, pp 11-15.

${ }^{22}$ European Commission, Increasing the Impact of EU Aid: A Common Framework for Drafting Country Strategy Papers and Joint Multiannual Programming, Communication from the Commission to the Council and the European Parliament, $\operatorname{COM}(2006) 88$ final, 2 March 2006, p 5.

${ }^{23} \mathrm{Ibid}, \mathrm{pp} 12-14$.

${ }^{24}$ Ibid, p 14.

${ }^{25}$ European Commission, Staff Working Document Accompanying the Communication 'Governance in the European Consensus on Development: Towards a Harmonized Approach within the European Union', SEC(2006)1020, 30 August 2006, p 11.

${ }^{26} \mathrm{Ibid}, \mathrm{p} 11$, italics added.

${ }^{27}$ D Kaufmann, A Kraay and P Zoido-Lobatón, Governance Matters, Policy Research Working Paper 2196, Washington, D.C.: World Bank, 1999. The dataset is available at http://info.worldbank.org/governance/wgi/index.asp, accessed 8 December 2009.

${ }^{28}$ The Communication on 'Governance in the European Consensus' announced the introduction of an incentive reserve related to countries' governance plans, amounting to $€ 2.7$ billion out of the $€ 22.6$ billion allocated to the 10th EDF. The incentive reserve would be distributed with the use of the governance profile on the basis of 'the assessment of the [governance] situation and the reform commitments given in the dialogue' (European Commission, Governance in the European Consensus, p 12). A recent paper Molenaers and Nijs indicates that the governance incentive has, so far, amounted to little more than a formal exercise. See: N Molenaers and and L Nijs, The Bumpy Road from Rhetoric to Reality: The EC on the Slippery Slope. Does the Governance Incentive Tranche Strengthen or Weaken Aid Effectiveness under the Umbrella of the Paris Declaration? Paper presented at the 12th EADI General Conference, Geneva, 2428 June 2008 . 